\title{
Aesthetics of Lurik Cloth for Adang Ceremony at Kasunanan Palace Surakarta Hadiningrat
}

\author{
FP. Sri Wuryani \\ Kriya lecturer of Indonesian Institute of the Arts (ISI) Surakarta, Indonesia
}

\begin{abstract}
The Adang Ceremony held at the Kasunanan Palace in Surakarta has an important meaning; firstly it is performed by a King as the ruler of a large kingdom in his time. The second is held only once every eight years, namely in the Dal year, as a form of Islamic religious broadcasting and the acculturation of Javanese culture with Islamic culture. Acculturation is reflected in the purpose of the ceremony, which is to commemorate the birthday of the Prophet Muhammad, the 13th of the month of Mulud, and to honor the ancestral spirits of the Kings of Mataram, as the forerunners of the Mataram Kingdom, especially the Kasunanan Palace of Surakarta. The three adang ceremonies are carried out using traditional equipment that is environmentally friendly. Adang uses Pusaka Dalem Dandang Kangjeng Kyai Dhudho, a Kasunanan Palace heirloom in the form of a large cormorant. Striated cloth is a ladder cloth and clothing of Dandang Kangjeng Kyai Dhudho in an adang ceremony. Striated cloth for ladder consists of various patterns: 1.Ciut Lurik Yuyu Sekandang Merah, 2. Ciut Lurik Yuyu Sekandhang Putih,3.Ciut Lurik Tuluh Watu Malang, 4.Ciut Lurik Tuluh Watu Mujur, 5.Ciut Luruk Pali,6.Ciut Lurik Gedong Madu, 7.Ciut Lurik Liwatan, 8.Ciut Lurik Poleng, 9. Ciut Lurik Uler Serit, 10. Sinjang Wiyar Lurik Kepyur, 11. Sinjang Wiyar Lurik Dengklung, 12. Sinjang Wiyar Lurik Tumbar Pecah, 13. Sinjang Wiyar Wari. The striated fabrics are folded, put in a tray and placed on the table together with other offerings. Sinjang Wiyar Lurik Dengklung is worn for the Dandang Kangjeng Kyai Dhudho cloth. The role of Sinjang Lurik Dengklung has a special meaning, namely as clothing for the heirloom of the Kasunanan Palace of Surakarta in the form of a Kyai Dhudho cormorant. The aesthetics of dengurung lurik cloth in an adang ceremony, viewed from 3 elements; shape, content and appearance. The shape or form, lurik cloth with dengklung pattern for adang ceremony, in the form of a long cloth / wiyar (in the form of a jarit / nyamping) measuring $90 \mathrm{~cm}$ wide and approximately 2.5 meters long, black with white stripes at both ends of the fabric. Appearance, to realize the Wiyar of lurik cloth with dengklung; it requires talent, skills and media. The manufacturing process, from natural materials namely cotton fibers made into yarn, woven with non-machine looms (ATBM) until become a lurik cloth, through a long and complicated process requires patience, painstaking, skills from beginning to ready to use. Appearance in the adang ceremony, Lurik Dengklung is used as a cloth of Dandang Kangjeng Kyai Dhudho, by being wrapped around the body of the cormorant and tied with white lawe yarn, requires skill to be neat and not easily separated. The combination that occurs in red, black and white. Red from the color of cormorant made from copper, black from lurik dengklung cloth, and white from the color of lawe yarn. The weight or content contained in the lurik dengklung, from the color combination that occurs namely red of the cormorant copper, the black lurik dengklung and the white of the lawe yarn. The color combination, as a symbol of fertility. The conditions that are expected from agrarian communities like Java, namely fertile land are expected to produce good crops. The white color is the symbol of the upper world (women) which brings rain, black is the symbol of the earth or the world below (men). Fertility will be achieved if there is a "marriage" (marriage of the cosmos), the upper world ie white or yellow with black, the underworld. The union of the two needs intermediaries, namely the middle world, symbolized by the red, the color of the red copper cormorant, as a symbol of the world in which humans live. Rice in the cormorant is transcendent (lucky), is believed to bring fortune, as a pest repellent and as a reinforcement. The fertility achieved brings peace, prosperity and cosmic order.
\end{abstract}

Keywords: adang, cormorant, lurik dengklung, symbol meaning

DOI: $10.7176 / \mathrm{ADS} / 77-03$

Publication date:October $31^{\text {st }} 2019$

\section{Introduction}

Kasunanan Palace of Surakarta is one of the heirs of the Kingdom of Mataram. The palace in Java and other Archipelago lost their power after World War II or precisely after the independence of the Republic of Indonesia. The kingdom or palace merges into one in the Unitary State of the Republic of Indonesia. They lost power over the area and position as the center of orientation of Javanese cultural values, customs and centers of Javanese arts. One of them is Kasunanan Palace of Surakarta, become the part of the Unitary State of the Republic of Indonesia. The role of the Kasunanan Palace of Surakarta / Javanese Palace is obliged to maintain the continuity of Javanese culture (Koencaraningrat, 1982: 235). Culture according to Van Peursen includes all human actions, such as the way he perceives death and make ceremonies to welcome the event, ... agriculture, hunting, how he makes tools, broken reinforcements, clothing, ways to decorate his home and body, ... (Van Peursen, 1976: 11). The palace cannot be separated from various kinds of traditional and religious ceremonies. The ceremony was 
held to honor the ancestors and asking God, to be given peace, tranquility, prosperity for the country or kingdom. The ceremony is manifested in events commemorating important events in the human life cycle, such as mitoni, circumcision, and other ceremonies. Traditional ceremonies have been carried out from several generations before, hereditary preserved until now, one of which is adang ceremony. The adang ceremony at Kasunanan Palace of Surakarta is one of the sacred ceremonies, namely the rice cooking ceremony conducted by the King and Queen. Adang ceremonies are held every eight years in Dal year according to Javanese years, to commemorate the birthday of the Prophet Muhammad and honor the ancestors. The adang ceremony was strung together with Garebeg Maulud, namely the discharge of the mountains from the Kasunanan Palace of Surakarta to the Great Mosque. The Great Mosque of the Kasunanan Palace of Surakarta is located in the west of the North Square. Adang ceremony or cooking rice here has a special meaning, different from adang which is carried out by the community in daily life. The aim is visually the same, namely to cook rice, from rice grains to rice that is ready to eat. The difference is the doer and the meaning behind the adang ceremony.

Adang ceremony is one of the forms of respect for the ancestors and a form of the closeness of the king to the subjects or people, the union of human with God. In particular, the empress accompanies the king in cooking rice, to be distributed to servants / people and guests present. An interesting event in this ceremony, is the use of lurik cloth to be put on (busanani) on a cormorant used to cook rice. Personification of a sacred cormorant, an inanimate object that is a cormorant like humans is given the name Kangjeng Kyai Dhudho, it is believed there is a spirit that inhabits it. The adang ceremony which had become a tradition before Islamic culture entered continues to the present with a distinctive form, the new form of culture as a blend of Javanese-Hindu culture with Islamic culture. The ceremonial process from beginning to end is seen as a form of cultural acculturation. Acculturation according to Young Yun Kim in Dedy Mulyana, acculturation is a process carried out by immigrants to adjust to local culture and obtain indigenous culture, which ultimately leads to assimilation (Dedy Mulyana, Jalaludin Rahmad, 1996: 139). We can interpret immigrants as foreign people who have their own culture to adapt to local culture. Islamic culture as a newcomer tries to communicate in order to enter Javanese culture as a local / native culture well, so that it can work together in a distinctive form of Islamic culture. This is reflected in the purpose and process of the adang ceremony. The purpose of the adang ceremony is to honor the ancestors of one of the forms of Javanese culture and to commemorate the birthday of the Prophet Muhammad as an Islamic culture. The process of the ceremony from beginning to end is full of nuances of Javanese culture and Islamic culture. The religion of Islam is reflected in the prayers that always accompany each part of the ceremony, from the beginning to the end of the adang ceremony, even in the Garebeg Maulud ceremony as the closing ceremony of the adang ceremony. Respect for ancestors is reflected in actions, ways of treating ancestral heritage and offerings (ubarampe) as a means that accompanies the ceremony. Lurik cloth is included as a means of adang ceremony. Lurik cloth in the adang ceremony is seen as one of the important means and must be available. Lurik cloth, although visually simple, in terms of style, material and shape, is considered important in adang ceremonies. Lurik cloth does not merely reflect one of the fashions worn by the ancestors of the Kings of Mataram and the people of its time, but has symbolic meaning related to the culture of Javanese society. The role and aesthetics (symbolic meaning) of lurik cloth for adang ceremony need to be studied and revealed. The focus of the research will be directed to the style and aesthetics of the lurik cloth used in the Adang ceremony at the Kasunanan Palace of Surakarta. Formulation of the problem, what is the style of lurik woven cloth for the adang ceremony in the Kasunanan Palace of Surakarta and what is the aesthetics (shape, content, and appearance)? The purpose of this research is to examine the aesthetics of the lurik cloth used in the adang ceremony, as a basis for the development of lurik cloth. The research method used uses qualitative research methods. The research data was collected from literature, observations at the Kasunanan Palace of Surakarta and places related to the problem and interviews with cultural observers, relatives of the palace and businessmen / lurik craftsmen. Data analysis uses an interactive model, the components used include: data collection, data classification (data reduction), data presentation and conclusions / withdrawal / verification (Tjetjep Rohendi Rohidi 1992: 20).

\section{DISCUSSION}

\section{Adang Ceremony at Karaton Surakarta}

Adang, is a term from Javanese $\mathrm{Ngoko}^{l}$ which means to cook rice. Cooking rice is a daily activity that is usually carried out by everyone, especially for women. Adang is a routine activity to meet the basic needs of the human body. Adang ceremony at Kasunanan Palace of Surakarta is a special activity that is carried out by the King of Kasunanan Palace of Surakarta namely ISKS Pakoeboewono and empress. This research took the moment of the adang ceremony in 2002, the adang ceremony held during the ISKS Pakoeboewono XII period. Sinoehoen was accompanied by Kangjeng Gusti Ratu Alit, Soesoehoenan's first daughter, because he did not appoint an

\footnotetext{
${ }^{1}$ Java Ngoko is a rough Javanese language, Javanese that is used in everyday conversation, with people of the same age or younger and are already familiar.
} 
empress. Adang ceremony in 2002 was the last ceremony conducted by ISKS Pakoe Boewono XII, because he died in 2004. He was replaced by the oldest son, KGPH Hangabei, who has the degree the ISKS Pakoeboewono XIII. Adang ceremony itself is a traditional ceremony that is carried out by the Kasunanan Palace of Surakarta regularly every eight years in Gondorasan. The ceremony involved various elements from the king to the courtiers / commoners, is a form of community social activities as gratitude as well as requests for safety for the next life. The ceremony according to Bachtiar, is a sociological perspective that emphasizes aspects of behavior, namely as a custom or habit that is carried out regularly according to a certain time and place, and certain events or needs (Bachtiar in Clifford Geertz, 1959: XII). Adang ceremony is carried out routinely and in the same place, namely in Gondorasan. The adang ceremony from 2002 to 2019 should have been held twice, in 2010 and 2018 , but the conditions in the Kasunanan Palace of Surakarta family did not support, the adang ceremony was not held.

The Adang Ceremony at the Kasunanan Palace of Surakarta uses the Kangjeng Kyai Dhudha cormorant ${ }^{1}$ heritage from the ancestors of the kings of Mataram, Supardi Suparlan in Clifford Geertz, (1959: XI), argues that offerings in slametan (ceremonies) are not always directed to ancestors but to spirits. Certain creatures for example mentioned the food served. Javanese heirlooms in Indonesia are believed to have inhabitants, inhabited spirits who are not regarded as ancestors, but rather as guardians or guardians of safety or well-being.

Adang is carried out traditionally using manual and natural equipment. Materials and equipment are prepared by ceremonies and prayers, aiming to ask for safety for the State / Kingdom and specifically for the smooth running of the adang ceremony itself. Adang Ceremony is a form of cultural acculturation, between Javanese culture and Islamic culture. One of the culture that is developed in the Surakarta Palace, as a means of honoring the spirits of the ancestors of the kings of Mataram and offerings to spirits. The adang ceremony is a form of Javanese culture, which developed before Islam entered the archipelago. Islamic culture entered Indonesia in the $15^{\text {th }}$ century, through trade routes (Clifford Geertz, 1959: 6, Koencaraningrat, 1982: 50). One of the broadcasts of Islam is utilizing local culture, namely Hindu-Buddhist cultural traditions, which at that time developed well inside and outside the palace. Koencaraningrat (1982: 54) writes the relationship between the aristocrats from the port cities and the nobles of the central palace of Majapahit continued due to marriage, thus the ideas in Islam infiltrated the culture of Majapahit palace, the Hindu-Buddhist cultural tradition that had been acculturated with Javanese culture. The teachings of Islam began to influence the mindset of the community; a distinctive Islamic culture / religion emerged that differed from the religion of Islam from its origin, namely the acculturation of Islamic culture with local culture. In Java came the Islamic santri, Islamic abangan and priyayi. Islamic Santri is people who obey and practice the teachings of Islam. The religious traditions of the santri not only consist of careful and orderly implementation of the subject of Islamic worship; prayer, fasting, pilgrimage, but also a complex whole of Islamic organization, generosity and politics. Islam Abangan refers to people who do not fully practice the teachings of Islam. The abangan religious tradition mainly consists of a ceremonial party called slametan, a complex and complicated belief in spirits, and a whole set of theories and practices of medicine, and magic. Priyayi on the one hand, the elite of employees whose roots lie in the Javanese Hindu palace before the colonial era, preserved and developed a very delicate palace ethics, highly complex arts in dance, drama, music and literature, and Hindu Buddhist mysticism. Priyayi emphasizes aspects of Hinduism and is associated with bureaucratic elements (Clifford Geertz, 1959: 6-8). So that abangan Islam in general is widely embraced by the priyayi or palace circles. The concept of God King, king as the incarnation of a god allows that a king in an ancient kingdom can establish royal government on the basis of the religious beliefs of his people. This condition can be easily used by others to take over the king's power, by conquering the royal capital and seizing the symbols and magic power of the king (Koencaraningrat, 1982: 41). Islamic culture through subtle and abusive methods entered the understanding of kings or rulers. Hindu-Buddhist culture which in fact Javanese Hinduism does not leave Javanese culture, believes that magic is a powerful energy that can emit heat, light or lightning. Supernatural powers or kasekten one of them contained in sacred objects, especially heirlooms (Kalff in Koencaraningrat, 1982; 341). Cormorant one of the heirlooms of the Kasunanan Palace of Surakarta is considered to have magical power used for an adang ceremony every eight years. An adang ceremony was held at the Kasunanan Palace of Surakarta which adhered to Javanese Hinduism before the colonial period, until the ISKS Pakoe Boewono XII period.

The adang ceremony is one of cultural acculturation, which took place in Java, especially in the Kasunanan Palace of Surakarta, producing a distinctive Islamic culture. The adang ceremony that existed before Islam entered Indonesia was a form of communication / closeness of the king with his subjects / people used to spread the teachings of Islam. The kings of the Kasunanan Surakarta in the adang ceremony symbolized the Batara Guru (king of the gods) symbolizing life and prosperity (Nian S. Djoemena, 2000: 84). Islamic teachings in the form of prayers are used in every part of the series of adang ceremonies. The meeting between the king and his

1 Kangjeng Kyai Dhudha Cormorant, is a cormorant for cooking rice with a distinctive form of copper named Kangjeng Kyai Dhudha, an ancestral heritage regarded as an heirloom and treated like other heirlooms. 
servants in the morning after the adang ceremony was completed, namely the event of handing out rice from the adang ceremony to the guests present. Rice from the adang ceremony is not eaten, but because it is believed to bring blessings, the farmers plant rice in the fields, so that they are not exposed to pests so that they get a good harvest. For traders, it is believed that it can give them many buyers or in demand, thus providing welfare for them (KRT Wirodiningrat, in Sri Wuryani, 2003); 128. Nian Djoemena (2000: 82), asserted that the Dal year was considered a year of blessing.

The purpose of the adang ceremonies carried out by the king and empress, as a ruler, is inseparable from the responsibility of welfare, peace, justice, security, tranquility for the whole community and country. The country which is gemahripah lohjinawi tata tentrem raharjo mirah sandhang lan boga. A universal hope is summarized in an adang traditional ceremony. Specifically summarized in lurik cloth used in clothing or offerings in bethak ceremonies. The phrase is so simple but full of meaning. The description and opinion of the informants revealed how deep and universal the meaning contained therein. The messages and expectations conveyed are not only valid in Java but are general in nature that can apply anywhere. As a reminder that in human life should always maintain cosmological balance and harmony namely the micro balance of the cosmos and macrocosm. Microcosmic balance is the balance and harmony relationships within each human person. It is manifested in cooperative relations or mutual cooperation in preparing adang ceremonies. The adang ceremony will not be carried out without the cooperation or mutual cooperation among (components of society) of the king as ruler / leader, sentono (royal family), pengageng parentah karaton (leaders / state officials), abdi dalem (people) and Islamic scholar (religious leader). This is a manifestation of the harmony of relationships between people, humans as social beings who always need others to live. The king is a symbol of a leader; a leader will not be able to create a country that is safe and prosperous without the cooperation of all elements of the country. It is also the balance of human relations with God who controls the universe as a divine organizer. Clerics who are always present at the ceremony incessantly recite prayers during the ceremony, implying the intention to remind leaders / rulers and the people (people / subjects) to always remember God to achieve a fair, prosperous, and peaceful and prosperity country. Macro, manifested in the selection of material taken from nature that is easily reunited with nature. Materials and equipment are taken or selected from areas that were once the power or ancestral tomb land; this implies the attitude of Javanese life which is always mikul duwur mendhem jero the name of the parents or ancestors. It means that children and grandchildren must remember the services of parents and ancestors as a predecessor. Ancestors are believed to always accompany their children and grandchildren as the successors of noble ideals as humans to achieve perfect human beings. Children and grandchildren are obliged to plant in the deficiencies and mistakes of their ancestors, but remember the good things as guidance or examples for their lives, without forgetting the bad things as a warning (Koesoemotanoyo, 2002).

\section{Adang Ceremony}

Adang ceremonies are held every 8 (eight) years or according to Javanese calendar, which is before the $12^{\text {th }}$ of Maulud every "Dal" year. The Dal year is considered to be a year of blessing (Djoemena, 2000: 82). 2002 coincided with the Dal year, the adang ceremony was held on the $10^{\text {th }}$ of Mulud in 1935 or May 26, 2002 AD, held at 20.0o wib, at Gondorasan Kasunanan Palace of Surakarta. Gondorasan is the name of a room in Palace to cook or kitchen. A place to cook when there are traditional ceremonies or religious ceremonies at the Kasunanan Palace of Surakarta. The location of Gondorasan is in the palace environment, which is to the south of the Museum of Surakarta Palace, faces south, can be accessed from within the palace through the South Sasono Sewaka (palataran) courtyard and from the Gondorasan gate facing south, and to the road located to the south of the Palace wall. Gondorasan generally has three rooms. The main house is located in the middle, consisting of a pavilion and rooms. The main house, everyday occupied by the family of Hadi's mother, who is trusted to manage Gondorasan. Second, the left side room of the main house, in the form of a kitchen that is used for cooking and preparing offerings and ubarampe, if there are ceremonies at the palace. The kitchen is equipped with traditional kitchen utensils such as a furnace, clay cooking utensils, tampah round shaped tray made of bamboo and other equipment. The third room is located on the right or the western part of the main house. This room is empty; this room is the place for the adang ceremony. The stove is made not permanent, it is only made when it will be used for an adang ceremony, after the ceremony is done, the stove is dismantled and milled / thrown into Parang Kusumo Selatan Laut along with other equipment that has not been used, (Sri Wuryani, 2003: 129).

Implementation of the adang ceremony in principle is to repeat (nostalgia) the process of cooking rice, Javanese language ngliwet or adang conducted by Dewi Nawangwulan the wife of Djoko Tarub, who is considered the ancestor of the Kings of Mataram. Dewi Nawangwulan is considered to be the incarnation of Dewi Sri (the goddess of rice), according to the beliefs which sent down kings in Java (Nian Djoemena, 2000: 84). Ngliwet or Adang is carried out as the beginning before getting to know and using modern equipment, which is manually / traditionally using pottery in the form of a cormorant, kendhil from clay, kukusan cone-shaped steamer made of bamboo woven. The ceremony was carried out from preparing rice from rice grain to rice ready 
to be served. The adang was preceded by a series of ceremonies from preparation to completion, ending with Garebeg Maulud. Preparations related to the needs of the adang, including procurement of rice by pounding rice with lesung ${ }^{l}$, procurement of wood, stove made of clay, kekep ${ }^{2}$ (crown) of clay, fire and so forth until ready for the adang ceremony. Material and equipment were taken from various places, areas that were once under the control of the Surakarta Palace and also from ancestral graves. Rice is obtained from pounding rice which is carried out in Gondorasan. Rice is brought by the servant, coming from fertile villages producing rice such as from Klaten and Delanggu. Nutu pari (pounding rice) is conducted by a servant in the palace, by placing rice in a lesung $\mathrm{kayu}^{3}$ and then pounded (ditutu) with alu from wood as well. Kepep, the clay cormorant cover, is made in Bayat, Klaten Regency. Clay for making stoves in the western part of Gondorasan was taken from Bayat. The fire to light firewood in the stove during the adang ceremony was taken from the tomb of Ki Ageng Sela in Purwadadi, Central Java, one of the ancestors of the Kasunanan Palace. Take water to nyirami (clean) Dandang Kangjeng Kyai Dhudha was taken from seven springs which are in the former area of the Kasunanan Palace. Equipment and materials were prepared before the ceremony was held on the $13^{\text {th }}$ of Mulud in 1935 Dal in the year of Java or May 26, 2002 according to AD.

The adang ceremony uses Kangjeng Kyai Dhudha cormorant ${ }^{4}$, prepared like a daughter-in-law. Put the tent in Gondorasan where the adang ceremony is held to start the event, which is to put up a kajang (coconut leaf tent), decorate it with leaves, prepare equipment and cook, prepare offerings and so on. The event continued with the carnival ceremony, which brought out Kangjeng Kyai Dhudha Cormorant from the storage room in the palace environment, brought to Gondorasan to be kept in the main room before the adang ceremony. In the main room various kinds of ubarampe and offerings have been provided to accompany the ceremony. Ubarampe or offerings, in the form of clothing from cotton cloth and lurik cloth, various types of food, as well as other equipment as needed for human life. Kirab is the next ceremony, which brings the cormorant from the heirloom gallery (storage room) in the palace to Gondorasan, and returns the cormorant after the ceremony is over from Gondorasan to the heirloom gallery to be stored for the next eight years. The next ceremony is siraman (cleaning / washing) for Kangjeng Kyai Dhudha. Kangjeng Kyai Dhudha Cormorant is placed on the table, then washed with water and cleaned by rubbing it so that it is clean. Then the cormorant is brought into the Gondorasan main house pavilion, placed on a table to be dressed (wrapped in lurik cloth). The cormorant is kept in the Gondorasan pavilion until the adang ceremony is finished. The night before the adang ceremony, the tirakatan night was held. It is filled with prayers in an Islamic way, to ask for a smooth running of the ceremony, for peace, safety, welfare of the nation and state.

Adang first begins with (m)busani (wearing clothes) Kangjeng Kyai Dhudha with a lurik cloth with dengklung style. Cormorant (Dandang) before dressed first smeared with perfume and jelly or opium. The lurik cloth with dengklung style is wrapped around the body of the cormorant and tied with a lawe / lawon yarn as if wearing a belt so it does not come loose. After mbusanani finished, then it is followed by cethik geni with the help of straw. Cethik geni, lighting firewood in a long-shaped stove with fire from the tombs of ancestors. The stove is equipped with several stove holes on the front and top. The front hole is where the firewood is inserted; the upper hole is for putting the cormorant and other cooking tools. The stove hole in the middle is for the Kanjeng Kyai Dhudho Cormorant. Cethik geni was preceded by Susuhunan's sons and daughters who were accompanied by Soesoehoenan (traditionally it should have been carried out by Soesoehoenan himself, but because Soesoehoenan was already elderly it was impossible to do it), followed by placing the heirlooms in Kangjeng Kyai Dhudha Cormorant and its penderek (other equipment) in the form of kenceng Kyai Godrag for ngaru, kendhil Nyai Rejeki and Kyai Tambur Cormorant on the stove. The fire in the stove was burning; the adang ceremony was ready to begin. Adang begins with $n g a r u^{5}$ using kenceng Kyai Godrag, until karon ${ }^{6}$ is ready to be moved to Kanjeng Kyai Dhudho Cormorant, which is ready with steam to cook rice until cooked.

Stories about events that took place during the adang ceremony were held, because it was believed that Kangjeng Kyai Dhudho Cormorant had magical powers. The magical power of the cormorant, according to the informants and from direct observations at the ceremony, among others, before the cormorant was used, it was first smeared with scented oil and jelly / opium on the outside by Ingkang Sinoehoen Kangjeng Soesoehoenan's sons and daughters. The powder from the jelly/opium will fade after the cormorant is used to cook rice, then the Kangjeng Kjai Dhudha Cormorant is powdered again with perfume and jelly, the cormorant position still above the stove, this is repeated again each time when the jelly fades until the ceremonial finish. This strange incident

\footnotetext{
${ }^{1}$ Lesung, a tool made of wood equipped with a pounder, to pound rice. It functions to separate rice from the skin.

${ }^{2}$ Kekep is the cover of Kangjeng Kyai Dhudha cormorant, made of clay which is considered a crown. Kekep was specifically ordered in the Bayat area of Klaten Regency.

${ }^{3}$ Lesung kayu, a tool to pound rice from wood.

${ }^{4}$ Kangjeng Kyai Dhudha Cormorant is a copper cormorant named Kyai Dhudha is ancestral heritage, considered a heirloom and treated like other heirlooms that are routinely given offerings.

${ }^{5} \mathrm{Ngaru}$ : boil the rice until it is half done, using kenceng.

${ }^{6}$ Karon: cooked rice that is only half done, and needs to be cooked again until done using a steamer equipped with steam to separate the water from the karon.
} 
occurred while smearing the cormorant, the hands of the Sinuhun's son did not feel the heat even though the cormorant remained in the position above the burning stove. The rice can immediately cook, even though the cormorants are larger than the normal cormorant size. Strangeness also occurs when adang, there are foreign guests present in the kitchen, then the rice cannot immediately cook / cook until the guest leaves the adang place, then the rice is cooked immediately. K.P.H.Wirodiningrat (late) said, once a restaurant owner in Sala, a friend of one of the sentono dalem was present at an adang ceremony, and rice in a cormorant was not immediately cooked even though according to the calculation the rice should have been cooked. After careful examination and from the instructions, it turns out that the restaurant owner is of Arab descent (not native). This event can also occur when cethik geni, the fire in the stove will not light, if there are strangers in the kitchen. The statement was justified by K.G.P.H. Hangabei (now ISKS PB XIII) said, for example I saw the adang ceremony eight years earlier, in 1994. When the ceremony was held, there were guests of Chinese descent came; the rice in the cormorant was not ready even though it had been long cooked. Other data stated that the rice had been steamed for five hours / not yet cooked, apparently there was a Japanese woman came, after being invited out of the room and the rice in a cormorant immediately cooked (Sri Wuryani, 2003: 126).

In the morning, a ceremony was held with the king to meet the courtiers, sentono and the community to distribute the rice from the adang ceremony. Rice was distributed to guests both from relatives and courtiers of the palace and residents present. Rice distributed is not to be eaten, but to be taken good luck or blessings (ngalab berkah). The farmers brought it home to be planted in the fields or in the garden, thus it is believed not to be attacked by pests and will get a good harvest (to reject reinforcement). If it is put into the rice container, it is believed that it will bring fortune. The adang ceremony continued with the tradition of Garebeg Mulud (Muludan), on the $13^{\text {th }}$ of the month of Maulud, the day of the birth and death of the Prophet Muhammad, on May 26, 2002 AD. Muludan is also regularly held in the Surakarta Palace every year apart from Dal year, which is by holding a sekaten and Garebeg Mulud celebration. The Sekaten is held for one week before the $13^{\text {th }}$ of Mulud. Sekaten is marked by the exit of the palace heirloom in the form of gamelan Kiyai Guntur Madu and Kiyai Sekati, from the Palace to the grand mosque. Sekaten closes with the entry of the gamelan back to the palace, and Garebeg Mulud celebration on the $13^{\text {th }}$ of Maulud, which is the discharge ceremony of the Kagungan Dalem gunungan lanang dan gunungan wadon, from the Palace to the Grand Mosque of the Kasunanan Palace of Surakarta, the gunungan will be distributed to the servant/the people present ( Koencaraningrat, 1994: 367). The Garebeg Maulud ceremony is one form of alms given by King to servants, by distributing food ingredients. Food ingredients are arranged together like a mountain (gunungan) called gunungan lanang (men gunungan) lan gunungan wadon (women gunungan). Gunungan Lanang is made from a variety of vegetables: long beans, eggplants, red chilies, and others arranged in cone shape resemble a mountain about 2 meters high. Gunungan wadon is made from rengginan and other food ingredients. Rengginan is food made from dried sticky rice in spherical round shape. The Great Mosque is located west of the North Square of the Kasunanan Palace of Surakarta. Gunungan arrived at the mosque, prayed by the cleric of Kasunanan Palace of Surakarta. The ceremony is finished, and then the gunungan is removed from the mosque and brought to the front porch of the mosque to be distributed to the people present. The community is waiting and ready to fight over it, there is a belief that if you get and keep part of the gunungan, you will get blessings.

\section{Aesthetics of Lurik Cloth for Adang Ceremony}

Lurik cloth is one of the best traditional textiles. Its creation is based on considerations related to Javanese culture expressed in lurik aesthetics. Aesthetics according to Djelantik (1999: 17-19,) objects or products contain aesthetic elements that are form or appearance, weight or content and appearance or presentation. The form consists of form and structure, the content consists of aspects: atmosphere, ideas and messages, appearance requires elements that play a role that is talent, skills and facilities or media. Tangible products form can be seen and touched. Appearance consists of form and structure. Form according to Djelantik, (1999: 20-32), in textile design is an important element, namely motifs, patterns or decoration: points, lines, fields and colors. Rizali (2013: 21) states that the concept of form globally is the totality of product appearance. It must be able to express the role of product functions as well as unity of the parts contained in the product (unity). The concept related to the Pedan Lurik Weaving according to the theory, is a unity of lines, colors and textures arranged in a composition according to the tastes and lifestyles of consumers in his time, then woven so that the lurik woven cloth in the form of fashion material (bakal kelambi), shawl, gloves, and others according to its function.

The structure or composition in question, the ways in which the basic elements of each of the arts have been arranged to form. The basic elements include shape, color, size, surface / texture, etc.). The arrangement includes a unique arrangement, so that there is a meaningful relationship between the parts of the whole embodiment, so that it is a certain ornament (Djelantik, 1999: 21). Structure according to Sewan Susanto, is an arrangement of the main motifs, supporting motifs and isen motifs. The main motive is a basic element, in the form of images of certain forms which will be the basis for naming a work or product. Supporting motifs are motives as elements that support the main motives, in the form of images of a particular form functioning to fill the fields between the 
main motifs. Isen motif, is a motif that serves to fill the main motifs and supporting motifs so that it looks beautiful (Sewan Susanto, 1980: 261; Dharsono, 2015: 49-50). The structure of its application in lurik, is the arrangement of lines or composition of lines. Lines as motifs, formed from colored thread. Motif, is the smallest element of the decoration / pattern. In lurik cloth, motifs are also called style, in the form of colored lines. The colored lines are arranged in a certain composition, then repeated again to form a horizontal, longitudinal and rectangular area. Gustami states, motifs are organized or arranged according to applicable principles, so that form units, with repetition of units according to the principles of repetition, will form patterns that decorate an object (Gustami, 1980: 7; Grosicki Z, 1975: 249-293). The motifs are arranged with a certain composition in one unit, according to the rules that apply in the design. The composition of these colored lines is the main motif in lurik, because the lines are arranged in accordance with the name of the style or lurik pattern that is standard. The names of the lurik cloth style, each of which has a different line and color arrangement and is standard. Yuyu sekandhang, gedhang flowers, or other style, are names of lurik cloth style that have a certain line structure, if the color or line structure change, then the name will change too.

Color is one of the elements in design and is a very important element in lurik cloth. Color as line forming, is an element of lurik cloth style that gives an aesthetic impression to the user or the audience. According to Sewan Susanto, color for the Indonesian people is a philosophy of life or supernaturalism. Color in the life of Javanese people in particular, has a meaning associated with belief and human life. This is reflected in various cultural products, sajen uba rampe ceremonies include colors that contain meaning as expressions of beliefs and customs. Keblat papat limo pancer, for example, illustrates the life force in kejawen called bayu (lust), which is symbolized into five colors, white, yellow, red, black and green, each of which has meaning (Sewan Susanto, 1973: 170-176, Bramantya, 2000: 305-306). Initially the existence of colors in lurik cloth refers to Javanese customs and beliefs. Color selection is considered according to function, meaning according to the wishes and desires of the maker. Subsequent developments are not fully adhered to; color selection is no longer entirely based on Javanese culture, but combines with the colors of prevailing fashion trends. Lurik cloth is developed into products for the needs of the present. The colors of lurik cloth today lead to bright colors, no longer always include black which gives the impression of masculine. Feminine impression is obtained by using orange, pink and so on (Musman, 2015: 115).

Texture or appearance of a luric cloth according to Djumena (2000: 33; Musman, 2015: 114), especially lurik cloth, is determined by the structure of the cloth including: the type of material used, such as natural fibers or synthetic fibers, types of yarn, hand made or hand-spun or machine-spun. Hand-spun yarn produces an uneven yarn surface, cloth surface or rough texture. Pedan Lurik Woven Cloth has finer textured than Gendhong lurik cloth, because it is made with factory-made yarn. Machine-made yarn, factory-made, has a flat, smooth surface. Texture is also influenced by the type of loom used, Gendhong loom or tijak loom (ATBM). Manual or gendhong looms produce denser or ketetalan ${ }^{l}$ yarn densities, so that produce denser woven cloth than cloth woven with ATBM semi-mechanical looms (Djoemena, 2000: 33).

Weight, according to Djelantik $(1999: 59,60)$ is the content or meaning of what is presented to the observer. Weights can be captured directly with the five senses or abstracts that require an explanation from the artist. Works that use symbols needs an explanation from the artist so that the meaning is understood, especially if it is only once seen. Even the adang ceremony at the palace is full of symbols in the form of offerings and ceremonies.

The adang ceremony uses a variety of equipment and is equipped with various offerings, in the form of flowers, food, drinks and clothing in the form of lurik woven cloth. G.P.H. Poeger in the interview said, one of the reasons for wearing lurik cloth at traditional ceremonies was to maintain the continuity of lurik. There are various patterns of lurik cloth for the ceremony. Lurik cloths for Kangjeng Kyai Dhudha offerings at adang ceremony in Dal year, from the notes in Gondorasan are: 1.Ciut Lurik Yuyu Sekandang Merah, 2. Ciut Lurik Yuyu Sekandhang Putih,3.Ciut Lurik Tuluh Watu Malang, 4.Ciut Lurik Tuluh Watu Mujur, 5.Ciut Luruk Pali,6.Ciut Lurik Gedong Madu, 7.Ciut Lurik Liwatan, 8.Ciut Lurik Poleng, 9. Ciut Lurik Uler Serit, 10. Sinjang Wiyar Lurik Kepyur, 11. Sinjang Wiyar Lurik Dengklung,12. Sinjang Wiyar Lurik Tumbar Pecah, 13. SinjangWiyar Wari (Sri Wuryani, 2003: 128). Lurik cloth has various styles, some of them are difficult to obtain, and even many of them are unfamiliar. Ciut Lurik Uler Serit and Ciut Luruk Pali, for example, many traders and craftsmen are unknown. There are many lurik cloth styles that are unknown or even extinct. Lurik cloth styles that are still known, the styles that are still used for traditional ceremonies that is still developing and carried out by the community. Lurik cloth used in the implementation of Adang ceremonies has a variety of styles but the important one is the lurik cloth with dengklung style. Nian S. Djoemena (2000: 57) writes: "Lurik Dengklung is used, among others . . . and adang ceremony. Unfortunately this lurik is almost unknown anymore, because it is rare and unknown anymore. Lurik cloth with dengklung used for adang ceremonies has nyamping form. Lurik cloth with dengklung style consists of two colors, black and white. Plain black color is on the cloth body and

${ }^{1}$ Ketetalan, the number of yarn per inch in the fabric/cloth. 
white lines as a drag / line on the edge. The black color gives the impression of calm, but the presence of white lines gives the impression of motion / dynamic. The overall impression is that there is a mystical and calm impression, the black color is reminiscent of the colors that are usually used by elderly people who are full of experience and have matured.

Pattern of the lines reflects simplicity. Simplicity is reinforced by the use of color and white, colors that have been known in prehistoric times. The black color as is the case with black background or black basic batik cloth is generally used by those who are old. Color that reflects the impression of old, mature in his life. Dengklung lurik cloth is also in black and white, also worn by parents as written by Isa Iskandar Usman: "Dengklung motif, worn by parents of the bride and groom on midodareni night". Dengklung lurik cloth worn on the night of Midodareni, can be interpreted as a reject reinforcement. The color combination of black and white is known as a sacred color. Black and white or blue and white are widely used as a repellent for danger, such as dabbing on the jenangan of the door of someone who has a baby, and other ceremonial purposes. Likewise, the intention to use a dengklung cloth at a midodareni event in a wedding is to reject reinforcement. When we look back on the condition of society in the past, there are many "people who has magic power", for good or evil purposes. One way to be on guard, the person who marries his child, making a "fence" around the house to anticipate things that are not wanted, one of which is to use a lurik cloth with dengklung style accompanied by fasting or other behavior (KoesoemaTanoyo (late), in Sri Wuryani, 2003, interview 3 April 2001). Another goal can be interpreted, that parents as people who have experience in life filled with ups and downs, can live well is an example for their children, especially for the bride. It is an example for his child to live a new life that will be taken. The bride and the bridal makeup are undergoing fasting a few days before and after the ceremony. The purpose is to pray with physical death, ask God to kalis ing rubeda kalis ing sambe kala/sakala-kala, avoid all disturbances and evil intentions of others, also to get the light of "divine light / holy spirit" so that the bride as a king looks beautiful and day handsome. Nian S. Djoemena interpreted as a symbol of parents in a special sense, namely:

"Lurik dengklung. Dengklung here is interpreted, compared to as a person who is extremely old, helpless and powerless, because of his age, but tumungkul (Javanese language), which is filled, knowledgeable, loaded with a variety of knowledge and experience. Lurik Dengklung with black and white color, which is the symbol of parents or elders. Not only old in age, but also full of experiences throughout the life cycle. Besides that, lurik dengklung is lurik to reject reinforcements. Because it is often also used for various ceremonies, offerings and also as a sacrifice for various things and events. Lurik dengklung is also used, among others, when dodolan dawet (selling cendhol) by the two brides' parents at the bride siraman ceremony, the belek belo ceremony and the adang ceremony (Nian Djoemena, 2000: 57)."

The quote is clear what is meant by Dengklung, interpreted as a knowledgeable parent, having knowledge here has a broad meaning, which is qualified (in charge) in science, good thought (ratio) and knowledge in the sense of spirituality. Javanese people always try to find a balance, harmony between physical and spiritual life to achieve perfection. The teachings of Java teach intelligence without being based on feeling, it will make a selfish human being who is only think about himself/herself, lacks a sense of tepa slira (tolerance), love for others, and so on, as social creature that is lack of social feeling towards fellow beings. Likewise, if only concerned with feelings, and lacking or does not have intelligence is less than perfect, because it will be a person who does not have the ability to work so less appreciated. Therefore between the ratio and taste there must be a balance. Mangkunegara IV's teaching that human beings must have primary behavior (feeling) and also three things namely: wirya, arta, and triwinasis (ratio and feeling) that have been alluded to previously, namely teachings that encourage or teach humans in daily life should have the main good behavior, courage because it is true, has wealth (arta / wealth), smart, clever and wise (Budiono Herusatoto, 2001: 21). Parents in the quote above, that "black and white lurik dengklung, which is a symbol of parents or elders, is not only old in age, but also full of experience throughout the life cycle." Mangkunegara IV in the teachings as written in the wedhatama book, old people is a person who has reached the perfection of life physically and mentally, someone who can control the little universe (microcosm), which is free from carnal lusts and draws closer to God. Lurik dengklung if associated with bethak or adang ceremonies, used by the Kangjeng Kyai Dhudha cormorant at the time of the adang ceremony, can be interpreted as a symbol to remind the leader in this matter especially for the king and his family (adang ceremony, specifically carried out by the king and empress, family), as leaders and aristocrats who become guidance, should be an example for others, servants, people. In general for everyone, it can be interpreted that in living life should not forget the noble teachings of the ancestors (old people) who are noble. If carried out, a perfect life will be achieved. Good guidance and behavior from the leader by governing fairly and wisely, the community will behave well and orderly, achieving the ideals of Negari dadosa gemahripah lohjinawi, tata tentrem raharja mirah sandhang lan boga, nyumarambahi sa-bumi (Yosodipura, KRMH,1982:5).

Lurik cloth with dengklung style in adang ceremony is wrapped around the body of the cormorant as if it was clothing. The compositions of colors that appear are three colors, namely white, red and black symbol 
of the cosmos, colors that were already known in prehistoric times. The red color, copper red is the original color of the cormorant made of copper. Black, the color of the lurik cloth with dengklung style and white color, the original color of the lawe yarn wrapped around to hold the lurik cloth.Yacob Soemardjo's opinion about the composition of the three colors as a triple pattern, which is common in cultivators or farmers. Cultivators live from planting, maintaining and developing rice, in principle, is alive. Life can continue if "marriage" unites two conflicting but complementary things, men and women who complement each other. Rice can grow if there is water (the upper world) and land (the lower world) that requires an intermediate (middle world) between the two, namely humans. The upper world, the middle world and the lower world cannot be separated. Color in relation to the adang ceremony, as a symbol of fertility that is very close to the condition of the agrarian region, such as the Indonesia, especially Java. The white color is the symbol of the upper world (women) which brings rain, the black symbolizes the earth or the lower world (men). Fertility will be achieved if there is a marriage of the upper world namely white or yellow with the lower world, the black color (marriage of the cosmos). The union of the two need intermediaries or mediums, that is, the middle world symbolized in red, in this case, the color of the red cormorant, the original color of copper, the world where humans live. Rice in the cormorant is transcendent (lucky), is believed to bring fortune, repellent pests and as a reinforcement. Fertility achieved will bring peace, prosperity and cosmic order, (Sumarjo, 2006: 72-77). The combination of the three colors on the cormorant in the adang ceremony as in the following picture.

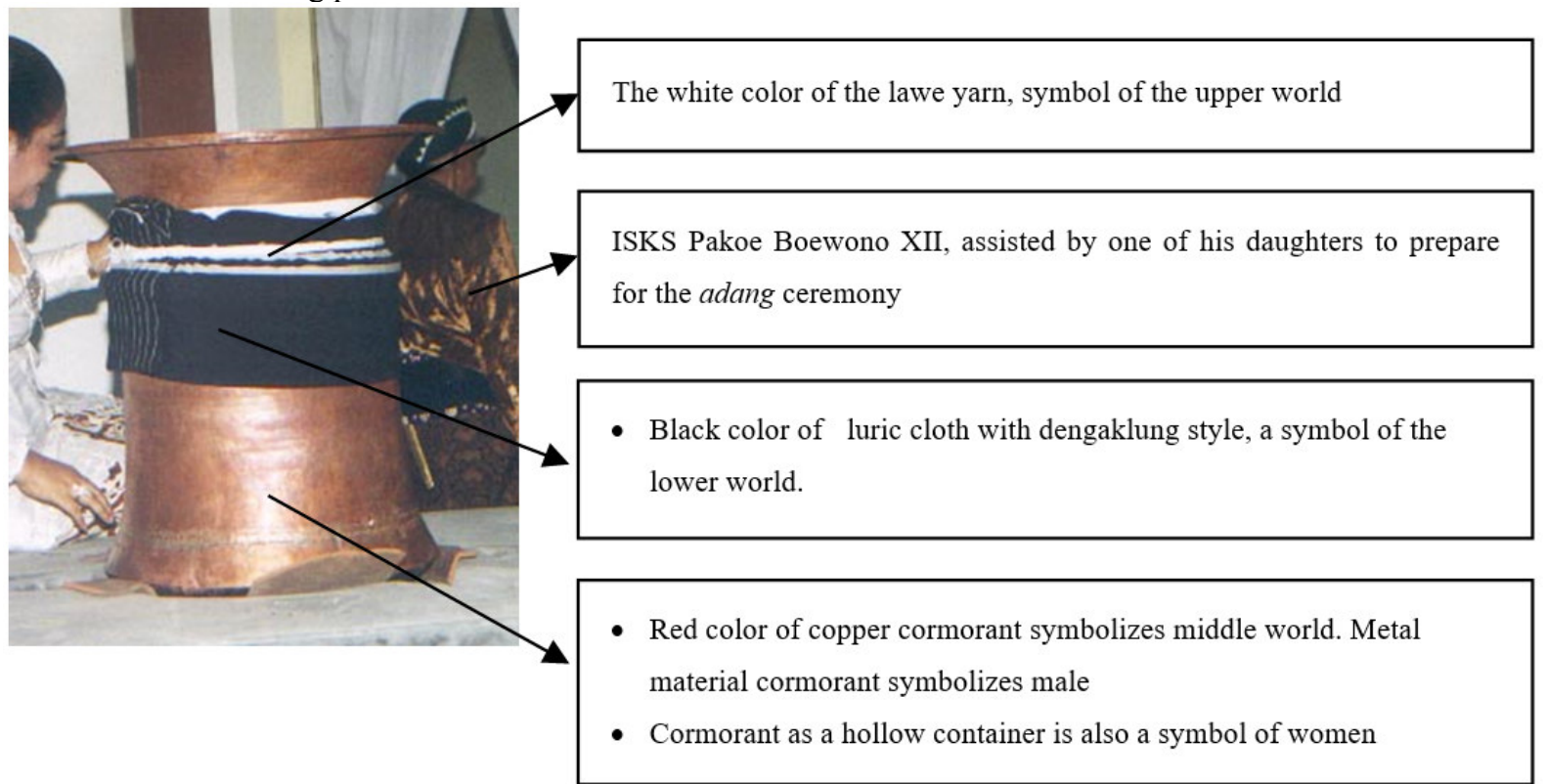

Picture 1. Kanjeng Kyai Dudo Cormorant is dressed with Lurik Cloth with Dengklung Style.

(Photo: Documentation by FP.Sri Wuryani, 2002)

The meaning of the symbol of the adang ceremony when viewed from the tools and ingredients in the form of a Kyai Dhudha cormorant and lurik cloth with dengklung style. Cormorant made of copper, one of the materials of the type of metal as a male symbol. Lurik cloth, the cloth is "soft" connotation of a female symbol. The merging of the two elements, namely metal, is "hard" in the form of a cormorant (male) with a cloth (female) wrapped around the cormorant, giving rise to a new life, namely rice in a transcendent cormorant. Another understanding of female character is found in earthenware objects. Earthenware vessel hollow that have women's connotations. In Minangkabau, earthenware used for cooking is placed on three stoves, upright massive. The stove is symbol of men, earthenware is symbol of women. Cuisine in it as a result of "marriage" both. The adang ceremony at Kasunanan Palace of Surakarta uses a hollow symbolizes a woman, on the inside which has a hollow water container at the bottom and rice at the top (in a steamer). It is put on three stoves made of clay; after adang finished, rice that has been cooked in the cormorant as the results of the "marriage" is transcendent. The distributed rice is believed bringing blessing, (Yacob Sumardjo, 2006: 184). This attitude of trust is usually conducted by Javanese people in general who like to "ngemum" expecting good luck / prayers on good things. Like pre-modern societies that does fasting or abstaining rituals and ceremonies in doing or making things. Premodern earthenware makers are generally conducted by women, as is the awe of batik and weaving is also made by women. In the process of making it, they often fast or abstain. Taking clay to make pottery was accompanied by a ceremony, (Yacob Sumardjo, 2006: 13). Even this ceremony was still held at the adang ceremony in 2002 at the Kasunan Palace in Surakarta, as KRT said. Wirodiningrat in the interview, took clay to make a stove in Gondorasan and a crown (cormorant cover) made in Bayat Klaten began with a ceremony. Religious ceremonies 
are also carried out for other activities such as: carving out Kanjeng Kyai Dhudho Cormorant from the gedhong heirloom in the Palace to Gondorasan, pounding rice (nutu pari) in Gondorasan, taking fire for cethik geni, to the tomb of Ki Ageng Selo ancestors of the Mataram kings in the Purwodadi area and during the implementation of the adang ceremony with ceremonies and constantly accompanied by prayers (remembrance) by scholars, relatives of the Kasunanan Palace of Surakarta and guests present, the last ceremony was a harbor to the Parangtritis beach of the South Sea coast to dispose the equipment and the remaining equipment that has not been used anymore. The South Sea has significance meaning for the Kasunanan and Yogyakarta palace. The sea is believed to be the Palace Kangjeng Ratu Kencanasari, better known as Ratu Kidul or the South Coast Queen of the South Sea ruler who maintains the safety of the Kasunanan Palace of Surakarta and Yogyakarta Sultanate. Yacob Sumardjo writes, the two Karatons are cosmic centers, guarded by four creatures / forces that control the four directions, namely East, South, West and North. This opinion is strengthened by Yosodipura (1982: 3) Javanese belief, namely the science of kejawen, Palace is a place where the visible and invisible (body / human and spirit) unite is also called the unity of the four directions or manunggaling keblat-papat.. Javanese believe that palace is guarded by spirits in four directions, namely: in the East guarded by Kangjeng Soenan Lawu, South guarded by Kangjeng Ratoe Kencanasari controls the South Sea, West is guarded by Ratoe Sekar Kedaton, controls Mount Merapi and North guarded by Kanjeng Ratu Kalayawati controls the Krendhawahono forest. Wirodiningrat / in the interview said, that the karaton routinely always held labuhan to the four directions, carried out every year when holding a memorial service of jumenengan, commemoration of the day / date of coronation of the king and at certain times such as the coronation ceremony of the king / appointment of a king. Based on the description above, it is natural that the rice from the adang ceremony is considered to be auspicious because of the accompanying prayers starting from the preparation, implementation and labuhan ceremony as a closing. Communities or people fight over ngalab berkah, even tools that have been anchored / dumped in the South Sea are believed to be lucky, so they are often contested.

Appearance in this case is viewed from how the lurik dengklung is made from yarn into cloth and the dengklung lurik cloth is used at an adang ceremony. Lurik cloth is designed not only to cover the body or genitals, but also full of meaning or content in accordance with the expectations of its users. The design needs to be realized and displayed, according to Djelatik (1999: 76-77) realizing it requires talent, skills and media. Showing or realizing lurik cloth from hundreds to thousands of strands of yarn, by being woven through several processes. Weaving work starts from providing media or materials, namely lawe from cotton fibers processed to twisting into yarn until it is ready to be woven, conducted manually by hand. Woven into a cloth in the form of nyamping, scarves, clothes or cummerbund conducted by hand, finally it is ready to use. Jobs that require precision, patience and skills. Skills that are a pride and must be had by a woman in the past, to meet the needs of the family. Therefore weaving is a job as well as a means of education, training patience, independence, educating to respect and utilize time with positive things for girls. Weaving work is a side job that is conducted every day for women, especially those who lived before independence and even today by some women, especially in the villages. Weaving work is passed down from generation to generation, so there is no doubt about talent and skills. Developments in all fields have influenced the community in interpreting the work of weaving and lurik cloth. Weaving work is defined as a complicated, boring and economically unprofitable job. The development of technology also makes it easier for ATBM lurik cloth crafters. Lawe yarn as a raw material has been widely produced by textile factories. Lawe yarn has been sold in the market or shop according to the desired color. Weaving equipment from Gendhong Weaving Equipment developed from ATBM to ATM, faster production, although the results were different. ATG is increasingly rare, being replaced by ATBM. The result is the lurik cloth made with woven ATG is denser, compared to woven cloth using ATBM. Lurik cloth that is used in palace with ATG scarcity, does not rule out the possibility of using lurik cloth made with ATBM, including dengklung lurik cloth for adang ceremonies.

Lurik cloth with dengklung style in Kasunanan Palace of Surakarta, used right at the adang ceremony in Gondorasan. Cormorant is considered as a human (personification) named Kangjeng Kyai Dhudho in a lurik cloth, as a medium for displaying / demonstrating dengklung lurik cloth. Lurik dengklung are folded according to the size of the cormorant, and then wrapped around the cormorant body neatly as if wearing clothes. Dengklung lurik cloth is tied with white lawe yarn so it does not come loose. Even this job requires skills and feelings so as to get a neat result, because applying (mbusanani) cloth to inanimate objects, namely cormorant as a display means, is different from wearing clothes on humans. Kangjeng Kyai Dhudho Cormorant is then placed on the stove, filled with water and installed with steam and then covered with kekep ready to be used for cooking / cooking rice until cooked, ready to be eaten / distributed.

\section{CONCLUSION}

Adang Ceremony, one of the ritual ceremonies held at Kasunanan Palace of Surakata. Adang itself generally has the understanding of cooking rice. Daily activities, especially for women cooking rice for daily meals. Adang, which was held at the Kasunanan Palace of Surakarta, had an important meaning because first, it was carried out 
by a king as the ruler of a large kingdom in his time. Second is it is held only once every eight years, namely in the Dal year according to the Javanese calendar, as a form of acculturation of Javanese culture and Islamic culture. Acculturation is reflected in the purpose of the ceremony, which is to commemorate the birthday of the Prophet Muhammad SAW, on the $13^{\text {th }}$ of Mulud month, and to honor the ancestral spirits of the Kings of Mataram, who became the forerunners of the Mataram Kingdom, especially the Kasunanan Palace of Surakarta. Third, adang ceremonies are held using traditional equipment that is environmentally friendly. Adang uses Pusem Dalem Dandang Kangjeng Kyai Dhudho, a Kasunanan Palace heirloom in the form of a large cormorant, a tool for cooking rice from copper, complete with steamer made from woven bamboo and other equipment. Ancestral heritage equipment, which has been centuries old.

The adang ceremony was held in Gondorasan, one of the Palace rooms which was used to prepare offerings and food for traditional Palace ceremonies. The preparation of the adang ceremony begins to prepare the materials and equipment directly related to the adang ceremony and the offerings and ubarampe needed. Materials and equipment from traditional / natural materials such as clay, rice taken from Bayat, Delanggu, Klaten areas that were once the authority of the palace and fire were taken from the tomb of Ki Ageng Selo, ancestor of the Kings of Mataram. Kirab was held to bring out and return Kangjeng Kyai Dhudho Cormorant to the gedhong heirloom where it was kept in the Palace. The adang ceremony is preceded by nyirami (cleaning) then mbusani Kangjeng Kyai Dhudho Cormorant with a jarit lurik dengklung (wrapping the lurik cloth on the body of the cormorant). Adang was held on the evening of the $10^{\text {th }}$ of Mulud, conducted by ISKS Pakoe Boewono XII accompanied by KGR Alit, his first daughter, because he did not appoint an empress. In the morning, the rice from the adang ceremony was distributed to relatives and guests present. Rice is considered can bring blessings so that rice is not eaten but it is brought to home, for example the farmers planted it in rice fields or tegal because the rice is believed to be able to avoid pests so that the harvest is good.

The ceremony was accompanied by ubarampe and offerings in the form of flowers, food and clothing in the form of batik cloth and lurik cloth. Lurik cloth as a laden cloth and as a clothing of Kangjeng Kyai Dhudho Cormorant. Lurik cloth for ladder consists of various patterns, i.e.: 1.Ciut Lurik Yuyu Sekandang Merah, 2. Ciut Lurik Yuyu Sekandhang Putih,3.Ciut Lurik Tuluh Watu Malang, 4.Ciut Lurik Tuluh Watu Mujur, 5.Ciut Luruk Pali,6.Ciut Lurik Gedong Madu, 7.Ciut Lurik Liwatan, 8.Ciut Lurik Poleng, 9. Ciut Lurik Uler Serit, 10. Sinjang Wiyar Lurik Kepyur, 11. Sinjang Wiyar Lurik Dengklung, 12. Sinjang Wiyar Lurik Tumbar Pecah, 13. Sinjang Wiyar Wari. The lurik cloth is folded, put in a tray and placed on the table together with other offerings. Only Sinjang Wiyar Lurik Dengklung, used for the Kangjeng Kyai Dhudho Cormorant cloth. The role of the lurik cloth as well as offerings also has a special meaning as clothing that is wrapped around the cormorant and tied with white lawe yarn so it does not come loose.

The aesthetics of dengurung lurik cloth for the adang ceremony at the Kasunanan Palace of Surakarta contain three elements, which are appearance, weight and appearance. The form of lurik cloth with dengklung style for adang ceremony in the form of nyamping cloth with a length of $2.5 \mathrm{kacu}$ width of 1 kacu, plain black with white drag on both ends of the cloth. Weight, when the cormorant used for ceremonies there are 3 color combinations. The color combination that occurs is the red copper color of the base material of the cormorant, black the color of lurik dengklung, and the white color of the lawe yarn. Color in adang ceremony, as a symbol of fertility. Conditions expected by agrarian regional communities such as Java, namely fertile land that produces good harvests. The white color is the symbol of the upper world (women) which brings rain, the black symbol of the earth or the lower world (men). Fertility will be achieved if there is a "marriage" of the upper world namely white or yellow with black that symbolizes lower world (marriage of the cosmos). The union of both needs intermediaries and mediums that is, the middle world symbolized by red, the color of the red cormorant, the original color of copper, as a symbol of the world in which humans live. Rice in the cormorant is transcendent (lucky), is believed to bring fortune, repellent pests and as a reject reinforcement. Fertility achieved will bring peace, prosperity and cosmic order. Appearance, dengklung lurik cloth is made from lawe yarn woven with ATG or ATBM by skilled and experienced weaving craftsmen. In general, they weave from childhood, inherit from parents or grandmothers or learn from neighbors. Its use in adang ceremonies, as a heirloom fashion of Dalem Kangjeng Kyai Dhudho belongs to the Kasunanan Palace of Surakarta, the inheritance of the ancestors of the kings of Mataram.

\section{References}

Geertz, Clifford. (1959). Abangan, Santri, Priyayi dalam Masyarakat Jawa. Pustaka Jaya. A.A.M, Djelantik. (1999). Estetika Sebuah Pengantar : Masyarakat Seni Pertunjukan Indonesia. Bandung. Usman, Isa Iskandar. (1988). Kain Tenun Lurik Tradisional di Yogyakarta. Bandung: ITB.

Koencaranirat. (1994). Kebudayaan Jawa. Jakarta: Balai Pustaka.

Matthew B. Mile, A. Michael Huberman (translated by Tjetjep Rohendi Rohidi). (1992). Analisis Data Kualitatif. Jakarta: Indonesia Press.

Musman, Asti. (2015). Lurik (Pesona, Ragam dan Filosofi). Yogyakarta: Andi Offset. 
Djoemena, Nian S. (2000). Lurik Garis-Garis Bertuah. Jakarta: Jambatan.

Sri Wuryani, FP. (2003) Kain Tenun Lurik, Tinjauan terhadap Sarana Upacara Bethak di Keraton Kasunanan Surakarta. Bandung: ITB.

Sumardjo, Yakob. (2006) Estetika Paradoks. STSI Bandung: Sunan Ambu Press.

KRMH, Yosopipura. (1982). Kabudayan Jawi Karaton Surakarta.

Peursen, Van. (1976). Strategi Kebudayaan. Yogyakarta: Kanisius.

Martowikrido, Wahyono. (1994) Lurik, Sejarah, Fungsi dan Artinya bagi Masyarakat. Jakarta.

\section{Informants}

Gusti Kangjeng Ratu Alit, (55), first daughter of ISKS. Pakoe Boewono XII Kasunanan Palace Surakarta.

Hadi. Mother. Gondorasan Kasunanan Palace Surakarta.

Hangabei, K.G.P.H. now ISKS. Pakoe Boewono XIII.

Koesoema Tanoyo, KRT. (75). Humanist, Purwodiningratan Surakarta.

Puger, GPH. (50). Humanist, Kasunanan Palace Surakarta.

Suryo, Mother. (70). Gondorasan, Kasunanan Palace Surakarta.

Wirodiningrat, KRT. (70). Pengageng Parentah Kasunanan Palace Surakarta ISKS Pakoe Boewono XII era.

\section{Appendix}

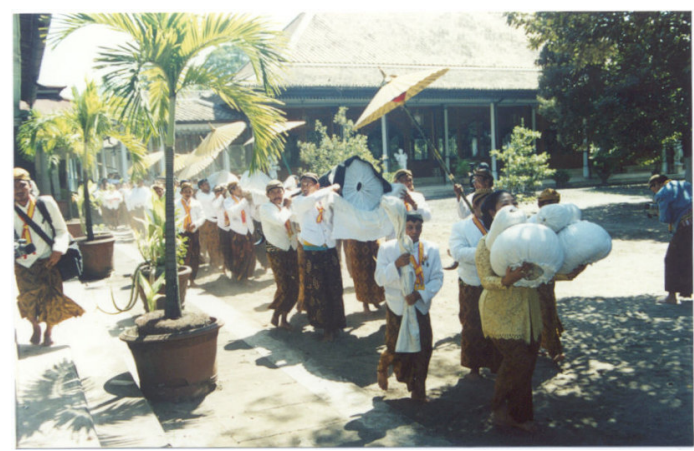

Picture 2: Kirab the exit of the Dandang Kangjeng Kyai Dhudho from the Storage Room to Gondorasan. (Photo: Documentation by FP. Sri Wuryani, 2002)

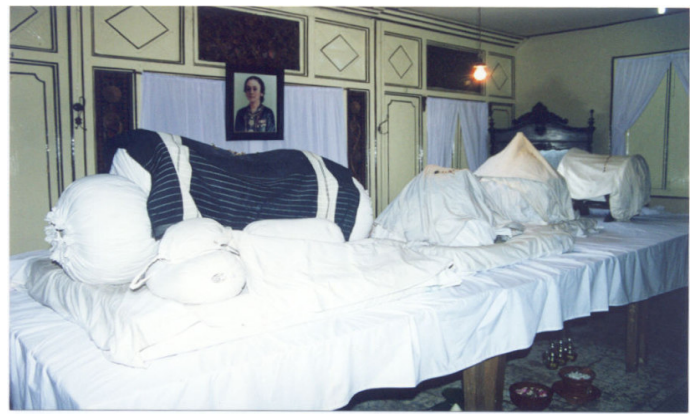

Picture 3: Dandang Kangjeng Kyai Dhudho di sareke

(put to sleep/saved) in Gondorasan

(Photo: Documentation by FP. Sri Wuryani, 2002)

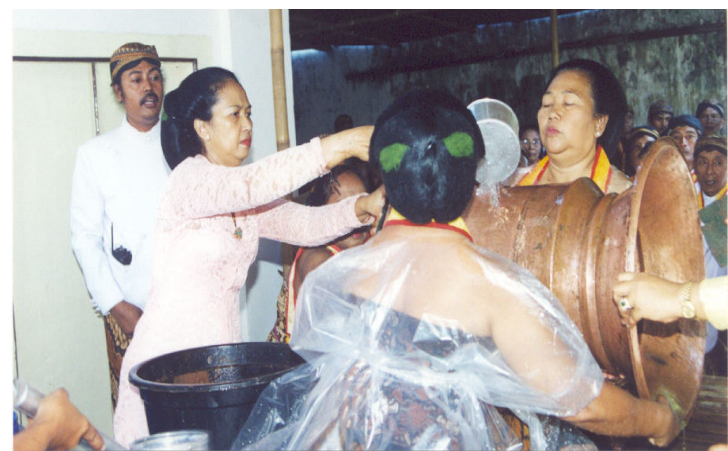

Picture 4: Dandang Kangjeng Kyai Dhudho di sirami (cleaned up) By GKR Alit assisted by abdi dalem, in Gondorasan. (Photo: Documentation by FP. Sri Wuryani, 2002) 


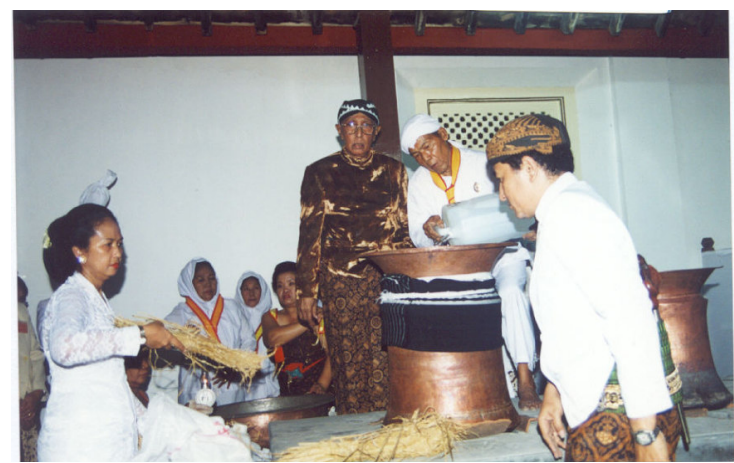

Picture 5: Gusti Kangjeng Ratu Alit and ISKS Pakoe Boewono XII, assisted by GPH Dipokusumo make a fire (cethik geni) to cook rice. (Photo: Documentation by FP. Sri Wuryani, 2002) 